\title{
Small-scale dynamics of secondary dispersal in a seagrass associated fish: a caging study
}

\author{
Sean M. Moran ${ }^{1}$, Gregory P. Jenkins ${ }^{2, *}$, Michael J. Keough ${ }^{1}$, Jeremy S. Hindell ${ }^{2}$ \\ ${ }^{1}$ Department of Zoology, University of Melbourne, Victoria 3010, Australia \\ ${ }^{2}$ Marine and Freshwater Resources Institute, PO Box 114, Queenscliff, Victoria 3225, Australia
}

\begin{abstract}
Secondary planktonic dispersal potentially alters recruitment patterns of marine organisms, but little is known about whether this process occurs in temperate fishes. This study investigated whether disturbance in seagrass beds, caused by onshore winds that induce high wave action, facilitated the resuspension and secondary dispersal of post-larval King George whiting Sillaginodes punctata (Cuvier). Cage inclusion experiments were conducted in seagrass beds within Port Phillip Bay, Australia. Live post-larvae were released into cages during 3 different wind conditions (onshore, alongshore and offshore) and their positions in the cage relative to the shoreline were recorded after $1 \mathrm{~h}$. Significantly higher numbers of post-larvae were collected on the seaward side of cages during high waves associated with onshore winds. Of these post-larvae, higher numbers were collected with increasing onshore wind speed. Our results suggest that physical disturbance, at the seagrass-bed scale, has the potential to alter recruitment patterns of $S$. punctata by facilitating secondary dispersal.
\end{abstract}

KEY WORDS: Physical disturbance - Secondary dispersal - Seagrass $\cdot$ Sillaginodes punctata Post-larvae

\section{INTRODUCTION}

For many marine organisms a critical stage in the recruitment process is the successful settlement from the pelagic environment into a benthic habitat. The settlement of larvae to such habitats can strongly shape recruitment patterns, and plays an important role in structuring population dynamics (Keough 1984, Roughgarden et al. 1988, Doherty \& Fowler 1994, Caley et al. 1996, Underwood \& Keough 2001). However, settlement is not necessarily the sole determinant of recruitment censused some time after settlement; for some taxa, post-settlement factors such as predation, food availability, habitat complexity, and disturbance also act to alter recruitment (Keough \& Downes 1982, Doherty \& Williams 1988, Connell \& Jones 1991, Connolly 1994b, Levin \& Hay 1996, Hixon 1998, Booth \& Hixon 1999). An additional process that can be important in structuring assemblages shortly after settlement is secondary planktonic dispersal (Rijnsdorp et al. 1985, Olivier et al. 1996, Turner et al. 1997, Etherington \& Eggleston 2000).
Most examples of secondary planktonic dispersal, characterised as the re-entrainment of settlementstage larvae into the surrounding water column from a benthic habitat, have come from marine invertebrates inhabiting soft-bottom environments relatively devoid of structure (Butman 1987, Commito et al. 1995), and seagrass beds (Etherington \& Eggleston 2000, Blackmon \& Eggleston 2001). The process of secondary planktonic dispersal has the potential to re-distribute larvae to new locations and alter initial recruitment patterns (Commito et al. 1995, Palmer et al. 1996, Thiebaut et al. 1996). Such re-entrainment into the water column can be passive, influenced by physical processes (Butman 1987, Commito et al. 1995, Turner et al. 1997) or an active behavioural response (Martel \& Chia 1991, Blackmon \& Eggleston 2001). To date, however, few examples of secondary planktonic dispersal have been found in fishes (but see Rijnsdorp et al. 1985).

The recruitment of fish to seagrass beds has been widely studied in temperate and tropical waters world- 
wide (Orth et al. 1984, Bell \& Pollard 1989, Orth 1992, Jenkins et al. 1996a). Much of this research has focused on how the effects of habitat structure (Heck \& Orth 1980, Jenkins et al. 1998a), predation (Levin et al. 1997, Hindell et al. 2000a,b), food availability (Connolly 1994a, Jenkins \& Hamer 2001) and larval supply (Hamer \& Jenkins 1996) influence fish recruitment and abundance. An early hypothesis by Bell \& Westoby (1986) suggested that fishes and invertebrate larvae settle indiscriminately among seagrass beds regardless of physical structure, and stay within that seagrass bed for up to a few months. This 'settle and stay' hypothesis, however, has been contradicted by evidence that suggests that fauna are highly mobile among seagrass beds (Sogard et al. 1989, Edgar \& Robertson 1992).

Recent studies in shallow seagrass beds suggest that wave disturbance generated by onshore winds may facilitate secondary dispersal for a number of seagrassassociated fishes (Jenkins et al. 1997, Moran et al. 2003). One species that may be particularly susceptible to secondary dispersal is the King George whiting Sillaginodes punctata. High-frequency sampling has shown that numbers of post-larval S. punctata declined in seagrass beds during high wave disturbance compared to calm conditions (Moran et al. 2003). Post-larvae of S. punctata enter Port Phillip Bay between September and November each year (Jenkins 1986). On arrival in the bay, postlarvae are between 90 and $150 \mathrm{~d}$ post-hatch and range between 16 and $20 \mathrm{~mm}$ in length (Jenkins \& May 1994, Jenkins et al. 1996b). Post-larvae are defined as having a full compliment of fin elements, but as yet to take on juvenile characteristics of pigmentation, gut-coiling and scale formation (Bruce 1995). The post-larvae of S. punctata have a number of similarities with pre-settlement larvae of tropical reef fishes. For example, S. punctata is a percoid, has a full compliment of fin elements, and falls within a size-range similar to that of reef fishes studied. However, Jenkins \& Welsford (2002) found the swimming capabilities of $S$. punctata post-larvae to be relatively weak, which supports the contention (gained through hydrodynamic dispersal models) that recruitment into Port Phillip Bay is largely a passive process (Jenkins et al. 1997, 1999).

Settlement of Sillaginodes punctata occurs in shallow reef and seagrass habitats (Jenkins \& Wheatley 1998). Early in the recruitment period, most post-larvae are close to the entrance of Port Phillip Bay, but over time numbers decrease in this area and increase in seagrass beds further inside the bay towards the Geelong Arm (Jenkins et al. 1996b). At present, hydrodynamic dispersal models and known larval behaviours have failed to explain the settlement of $S$. punctata to seagrass beds located in the Geelong Arm on the western side of Port Phillip Bay (Jenkins et al. 1997, 1999). The aim of this study, using cage inclusion experiments, was to assess whether wave disturbance generated by onshore winds can facilitate secondary dispersal in S. punctata post-larvae. This study quantitatively examined fine-scale fish movements during varying physical disturbance regimes, and has the potential to further explain recruitment dynamics of demersal fishes.

\section{MATERIALS AND METHODS}

Study site. This study was done at Grassy Point, situated on the NE shore of the Bellarine Peninsula of Port Phillip Bay (Fig. 1). Port Phillip Bay is a large semienclosed, predominately tidal embayment in SE Australia that is connected to the oceanic waters of Bass Strait (Fig. 1). Tidal currents in the region of our site are generally weak ( 0.1 to $\left.0.2 \mathrm{~m} \mathrm{~s}^{-1}\right)$ compared to the strong tidal currents at the Bay's entrance $\left(3 \mathrm{~m} \mathrm{~s}^{-1}\right)$ (Black et al. 1993). Tides in Port Phillip Bay are semidiurnal, with a range of less than $1 \mathrm{~m}$. In the shallow subtidal at Grassy Point, beds of eelgrass Heterozostera tasmanica (Martens ex Aschers) den Hartog run parallel to the shoreline. These narrow bands of seagrass (20 m wide) are interspersed amongst patches of bare sand. Wave height in the study area ranged from less than $5 \mathrm{~cm}$ in offshore winds to $0.4 \mathrm{~m}$ in the strongest onshore winds of approximately 10 to $11 \mathrm{~m} \mathrm{~s}^{-1}$.

Cage experiment. We positioned 3 replicate $5 \times 5 \mathrm{~m}$ fine-mesh cages within Heterozostera tasmanica beds at Grassy Point at an average depth of $0.8 \mathrm{~m}$ below mean low-water spring tide. Each cage was con-

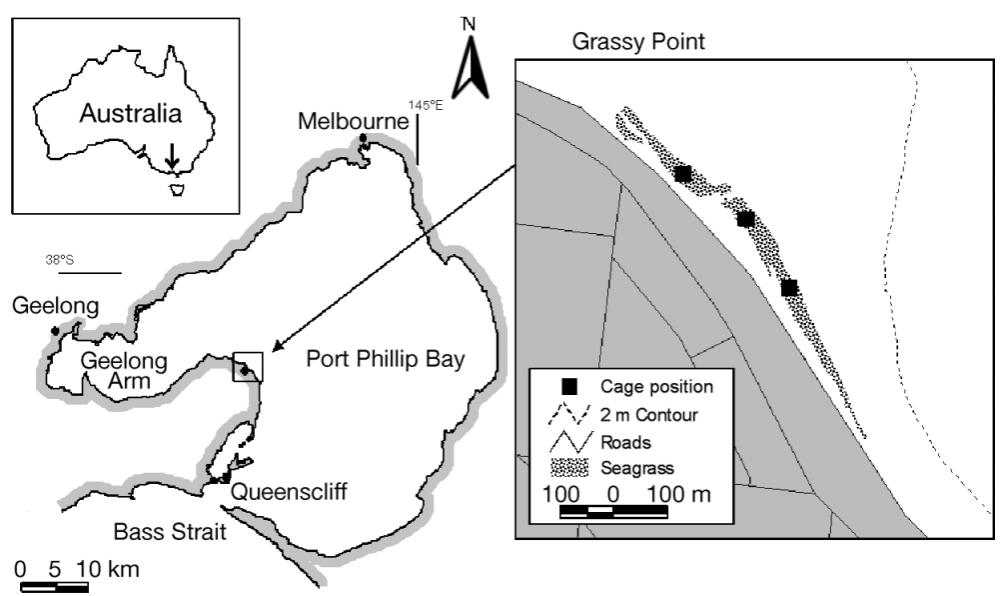

Fig. 1. Port Phillip Bay, SE Australia. Inset: Grassy Point showing positions of cage structures in seagrass 
structed of 12 evenly spaced, $2.1 \mathrm{~m}$-long galvanised steel poles hammered into the substrate. Around these poles we attached a $20 \mathrm{~m}$ length of $1 \mathrm{~mm}^{2}$ black fibreglass netting (1.6 $\mathrm{m}$ in height), enclosing an area of $25 \mathrm{~m}^{2}$. The mesh was tightened at the top and bottom and tied to each pole with $5 \mathrm{~mm}$ nylon cord and plastic clamps. The bottom of the net was weighted with a lead rope to prevent fishes swimming between the bottom of the cage walls and the top of the substrate. At all times throughout the experiment, the water level did not exceed the top of the cage walls, and the substrate remained submerged. The placement of each cage was selected at the beginning of the experiment, and plots were sampled repeatedly during each wind condition through time. Cages were separated from each other by approximately $75 \mathrm{~m}$. Cages were oriented parallel to the shoreline, with the shoreward side of the cage approximately $3 \mathrm{~m}$ from the shoreward edge of the seagrass bed (Fig. 2). A gradient of less than $3^{\circ}$ was measured between the shoreward and seaward edges of each cage.

Following construction, each cage was cleared of fishes and drift algae with a $6 \mathrm{~m}$ long $\times 2 \mathrm{~m}$ high $\times$ $1 \mathrm{~mm}^{2}$ mesh beach seine net; 2 people deployed the seine net. Seine-net techniques and methods used to catch post-larvae are described in detail by Jenkins et al. (1996b). On removal of the fishes, the cages were left undisturbed for at least 15 min prior to beginning the experiment.

At approximately 5 to $7 \mathrm{~d}$ intervals, Sillaginodes punctata post-larvae were collected from Heterozostera tasmanica beds in the vicinity of experimental cages at Grassy Point. These fish were caught during calm weather conditions along the same depth contour as the cage structures. Post-larvae were collected on calm days to eliminate any bias in the behaviour of individual fish during different weather conditions. Fish were collected with a $10 \mathrm{~m}$ long $\times 2 \mathrm{~m}$ high $\times$ $1 \mathrm{~mm}^{2}$ mesh beach seine net; 2 people slowly hauled in the net until a small enclosed circle remained. The fish were then carefully transferred to 201 plastic tubs filled with seawater and transported to the Queenscliff Marine Station (20 min by road). On arrival, the fish were transferred to a series of 2001 holding tanks filled with re-circulating seawater at ambient temperature $\left(19^{\circ} \mathrm{C}\right)$ and fed brine shrimp daily until used in the caging experiment. No fish were kept in the holding tanks for longer than $4 \mathrm{~d}$.

Fish were introduced to cages at approximately 1 to $4 \mathrm{~d}$ intervals from mid-September to early November 2001; 2 cages were used on each sampling day; 1 person slowly released 25 fish in the centre of each cage. Visual observations during pilot studies suggest that fish introduced in this manner were not subjected to increased turbulent forces that could have affected

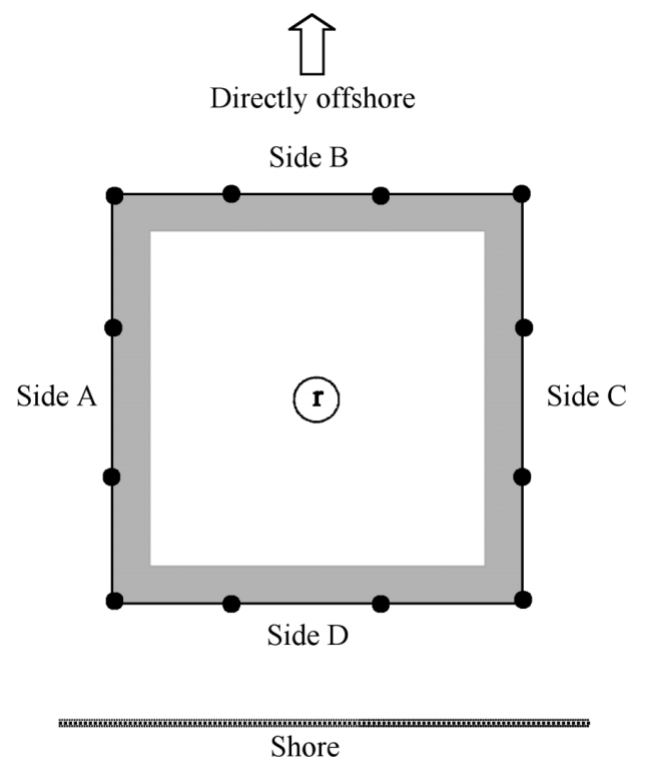

Fig. 2. Structure of cages $(5 \times 5 \mathrm{~m})$ used in recapture experiment. Shaded area represents section of cages sampled. Diagram also shows cage sides (A-D), orientation of cages relative to shoreline, and the fish-release point, $r$

their swimming capability or caused physiological damage. Fish were left in cages for $1 \mathrm{~h}$ before sampling. As the mean currents in the sampling area range from approximately 2 to $30 \mathrm{~cm} \mathrm{~s}^{-1}$ (K. P. Black et al. unpubl. data), this would allow more than enough time for passive transport of post-larvae to the side of the cage. Each side of the cage was sampled with a $1.5 \mathrm{~m}$ long $\times 0.4 \mathrm{~m}$ wide $\times 0.25 \mathrm{~m}$ deep dip-net. The dip-net was made from a $25 \mathrm{~mm}$ diameter PVC rectangle frame with $1 \mathrm{~mm}^{2}$ black mesh attached. The bottom of the net was weighted with lead and the top buoyed with small floats. Sampling was conducted by placing the net at a corner of the cage (long side held vertically), and then walking the net along each side of the cage to the next corner (maintaining the side of the net against the side wall of the cage). Each cage wall was sampled 4 times (i.e. 4 rotations) on each sampling date to ensure that no fish were missed during sampling. The first side sampled was chosen randomly, and all sides of the cage were sampled once before the next round of sampling started. Underwater visual observations during pilot studies had suggested that the operation of this type of dip net accurately represented fish numbers along the sides of cage structures (i.e. capture efficiency for 1 sweep averaged $90 \%$ success rate). All fish collected on each side were removed, anaesthetised in benzocaine and placed in ethanol. In the laboratory, standard lengths (SL; tip of snout to the tip of caudal peduncle) were recorded. 
Cage effects. Physical measurements were taken to assess the effects of the cage on flow. On 14 November 2001, an S4 current meter was deployed in the centre of a cage. The current meter was mounted on a concrete block and stainless steel pole, with measurements taken approximately $0.5 \mathrm{~m}$ above the substrate ( 0.35 to $0.4 \mathrm{~m}$ above the seagrass canopy). The water depth was approximately $1.25 \mathrm{~m}$, the tide was at the top of the flood, and winds were light ( 2 to $3 \mathrm{~m} \mathrm{~s}^{-1}$ ) from the southeast. Measurements were taken at $1 \mathrm{~min}$ intervals for $10 \mathrm{~min}$ periods. We alternated $10 \mathrm{~min}$ periods of measurements taken with the cage mesh in place with periods without the cage mesh, until 3 periods each of cage mesh and no cage mesh were recorded.

At the end of the cage experiment on 22 August 2000, a fast-response 3-dimensional Acoustic Doppler Velocimeter (ADV, Sontek) was deployed on a stainless steel frame in the centre of a cage to examine the effect of the cage mesh on wave and turbulence characteristics. The frame was carefully levelled so that the horizontal $(u, v)$ velocity components did not contaminate the vertical $(w)$ component.

The ADV was set to record at $16 \mathrm{~Hz}$ and the water temperature was measured with a submersible thermometer at the start of each profile and set in the instrument's software. The water depth was approximately $1.35 \mathrm{~m}$, winds were onshore at approximately $5 \mathrm{~m} \mathrm{~s}^{-1}$, and the tide was in the mid- to late flood. Measurements were taken for $5 \mathrm{~min}$ with and without the cage mesh at approximately $0.45 \mathrm{~m}$ above the substrate ( 0.3 to $0.35 \mathrm{~m}$ above the seagrass canopy).

The ADV records a signal-to-noise ratio and correlation coefficient for each signal beam that can be used to assess the quality of each measurement. With the manufacturer's software, filtering was achieved with the correlation coefficient for each signal beam set to a threshold level of $70 \%$ and $5 \mathrm{~dB}$ for the signal-to-noise ratio. The data was then further de-spiked, assuming that any natural acceleration could not exceed $1 \mathrm{G}$. The filtering generally eliminated less than $10 \%$ of the time series recorded in the water column.

Environmental variables used in study. Wind directions were recorded at the time of sampling. We assigned 3 classifications of wind direction: onshore, offshore and alongshore. Because the shoreline at Grassy Point is orientated approximately NW-SE (see Fig. 1), winds from the north around to the E-NE were therefore classified as onshore winds. Wind from the south to W-SW quadrant was subsequently classified offshore. All other wind directions were categorised as alongshore. At this site, onshore winds are highly correlated with high wave disturbance, while offshore winds represent calm weather associated with low wave heights. Furthermore, due to the orientation of the coastline, alongshore winds tend to wrap around the headland and direct waves shoreward, resulting in similar wave disturbance to that generated by onshore winds. Wind speeds were collected from a meteorological weather station located at Point Cook, approximately $20 \mathrm{~km}$ from our study site.

Statistical analysis. The cage experiment was analysed as a repeated-measures 3-factor analysis of variance (ANOVA), with wind condition (onshore, alongshore, offshore), cage side and cage location as fixed factors. The side of cages was the repeated factor. Cages were placed in specific positions to ensure that they related to a parallel hydrodynamic study conducted at this location at Grassy Point (K. P. Black et al. unpubl. data). In all, 6 replicate days for each wind condition were used throughout the experiment. Data were proportions of the original number of fish collected on each cage side, which were arcsine-transformed to satisfy the assumptions of normality and homogeneity of variances. Not all fish were recaptured on each sampling occasion, so data were not constrained to sum to 1. The assumption of sphericity was checked by the Greenhouse-Geisser (G-G) epsilon value $(\varepsilon)$. A separate analysis of variance was used for each location to explain significant interactions between main effects from the repeated measures ANOVA model. Tukey's tests $(\mathrm{p}<0.05)$ were used for post-hoc comparisons of significant main effects in the above models. Regression analysis was used to investigate how the proportion of fish collected along cage sides varied with wind speed.

Variation in standard length (SL) on different cage sides was investigated with a 2-factor ANOVA, with wind condition and cage side treated as fixed factors. Unlike the above analyses, a repeated-measures model could not be used because of the large number of 'missing cells' in our data (e.g. when no fish were collected on a particular cage side on a given day). Significant main effects were investigated with Tukey's test $(\mathrm{p}<0.05)$.

Power spectra for speed components in the $u, v$ and $w$ from the ADV measurements were obtained from the acquired 5 min time series using the fast fourier transform (FFT) technique. A window of 1024 data points was used.

\section{RESULTS}

The proportion of Sillaginodes punctata post-larvae recaptured from different cage sides varied with wind direction (Table 1, Fig. 3). Overall, 62\% of released post-larvae were recaptured during onshore winds, while 51 and $23 \%$ were recaptured during alongshore and offshore wind conditions respectively. Separate 
Table 1. Sillaginodes punctata. Results of 3-factor repeated measures analysis of variance (ANOVA) comparing numbers of fish amongst cages and wind conditions (onshore, offshore and alongshore). Data were arcsine-transformed prior to analysis. Bold values indicate significance at $p<0.05$

\begin{tabular}{|lrrrr|}
\hline Source & df & MS & $F$ & \multicolumn{1}{c|}{ p } \\
\hline Between subjects & & & & \\
$\quad$ Wind (W) & 2 & 0.246 & 7.502 & $\mathbf{0 . 0 0 3}$ \\
Cage (C) & 2 & 0.018 & 0.510 & 0.606 \\
W $\times$ C & 4 & 0.024 & 0.684 & 0.609 \\
$\quad$ Residual & 27 & 0.035 & & \\
Within subjects & & & & \\
$\quad$ Side (S) & 3 & 1.288 & 32.462 & $<\mathbf{0 . 0 0 1}$ \\
S $\times$ W & 6 & 0.089 & 2.239 & $\mathbf{0 . 0 4 8}$ \\
S $\times$ C & 6 & 0.052 & 1.314 & 0.261 \\
S $\times$ W $\times$ C & 12 & 0.042 & 1.051 & 0.412 \\
Residual & 81 & 0.040 & & \\
& & & & \\
\hline
\end{tabular}

2-factor ANOVAs used to investigate the significant interaction between wind direction and cage sides showed the proportion of fish at the seaward side (Side B) varied significantly amongst wind conditions (Table 2). Post-hoc tests showed that more larvae were concentrated on the seaward side of cages (Side B) during onshore than offshore wind conditions (Tukey's test, $\mathrm{p}=0.003$; Fig. 3), with numbers falling by $\sim 75 \%$. Additionally, the proportion of recaptures along the seaward side (Side B) did not vary between onshore and alongshore wind conditions (Tukey's test, $\mathrm{p}=$ 0.372) and, although a trend suggests otherwise, alongshore and offshore wind conditions also did not vary (Tukey's test, $p=0.071$; Fig. 3). Furthermore, the proportion of larvae recaptured did not vary amongst cages at Grassy Point (Table 1). Recapture rates of post-larvae along Side B varied in response to wind strength, with a significant relationship between the proportion of post-larvae recaptured and onshore wind strength ( $\mathrm{n}=12, \mathrm{r}^{2}=0.451, \mathrm{p}=0.017$; Fig. 4). However, a similar relationship was not found for offshore $\left(\mathrm{n}=12, \mathrm{r}^{2}=0.015, \mathrm{p}=0.705\right)$ or alongshore $(\mathrm{n}=12$, $\mathrm{r}^{2}=0.147, \mathrm{p}=0.218$ ) wind conditions.

A high proportion of fish (>60\%) were re-captured on 5 sampling days. On 2 of these days, winds were onshore, while on the other $3 \mathrm{~d}$ winds were alongshore. The highest recapture rates were found during onshore winds on 10 and 22 October, when 98 and $96 \%$ of fish were re-caught respectively (Fig. 5). Of these fish recaptured, 90 and $72 \%$ were collected along Side B respectively (Fig. 5). On these dates, wind strength was $>10 \mathrm{~m} \mathrm{~s}^{-1}$ from the NE, which was the strongest onshore wind strength observed throughout our study. During alongshore winds, the highest recapture rates were on 1, 18 and 25 October, when 66, 80 and $68 \%$ of the fish were re-caught respectively. On 1 and 18 October, the

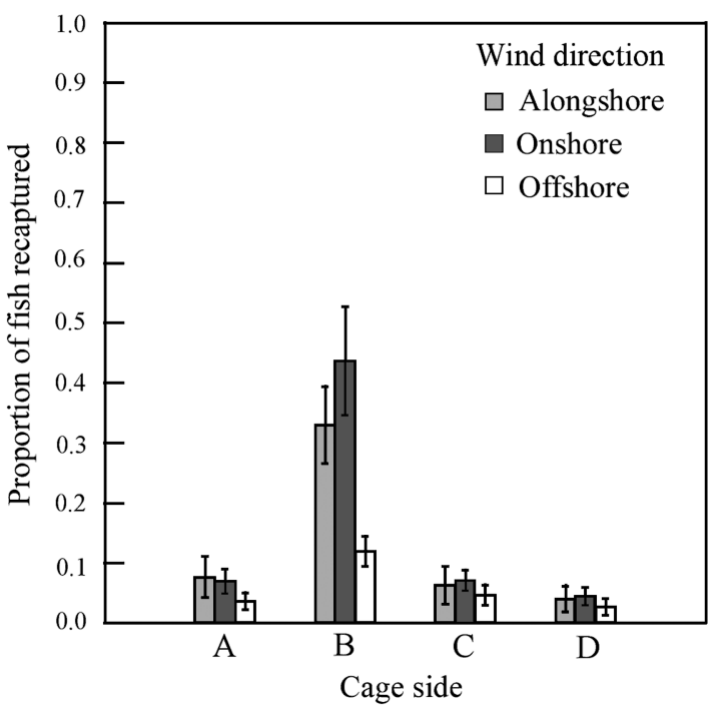

Fig. 3. Sillaginodes punctata. Effects of wind condition (alongshore, onshore, offshore) and cage side (A-D) on mean proportion of post-larvae recaptured in cage structures. Means ( $\pm 1 \mathrm{SE}$ ). For each wind condition, a total of 300 post-larvae were placed in cage structures

proportion of recaptures along Side B dominated this result (52 and $54 \%$ respectively; Fig. 5), while on October 25 the proportion of recaptures along Side B was lower (26\%) and similar to that for Side C (24\%; Fig. 5).

The standard lengths of recaptured Sillaginodes punctata did not vary significantly amongst cage sides

Table 2. Sillaginodes punctata. Results of 2-factor analysis of variance of proportions, with side analysed separately for effects of cage and wind direction (onshore, offshore, alongshore). Data were arcsine-transformed prior to analysis. Bold values indicate significance at $p<0.05$

\begin{tabular}{|lrccc|}
\hline Source & df & MS & $F$ & $\mathrm{p}$ \\
\hline Side A & & & & \\
$\quad$ Wind & 2 & 0.028 & 0.978 & 0.389 \\
$\quad$ Cage & 2 & 0.030 & 1.036 & 0.368 \\
$\quad$ Wind $\times$ Cage & 4 & 0.037 & 1.298 & 0.296 \\
$\quad$ Residual & 27 & 0.029 & & \\
Side B & & & & \\
$\quad$ Wind & 2 & 0.485 & 6.912 & $\mathbf{0 . 0 0 4}$ \\
Cage & 2 & 0.112 & 1.590 & 0.222 \\
$\quad$ Wind $\times$ Cage & 4 & 0.058 & 0.831 & 0.518 \\
$\quad$ Residual & 27 & 0.070 & & \\
Side C & & & & \\
$\quad$ Wind & 2 & 0.007 & 0.212 & 0.811 \\
Cage & 2 & 0.008 & 0.235 & 0.792 \\
Wind $\times$ Cage & 4 & 0.017 & 0.520 & 0.721 \\
$\quad$ Residual & 27 & 0.033 & & \\
Side D & & & & \\
$\quad$ Wind & 2 & 0.010 & 0.450 & 0.642 \\
$\quad$ Cage & 2 & 0.025 & 1.146 & 0.333 \\
$\quad$ Wind $\times$ Cage & 4 & 0.036 & 1.657 & 0.189 \\
$\quad$ Residual & 27 & 0.022 & & \\
\hline
\end{tabular}




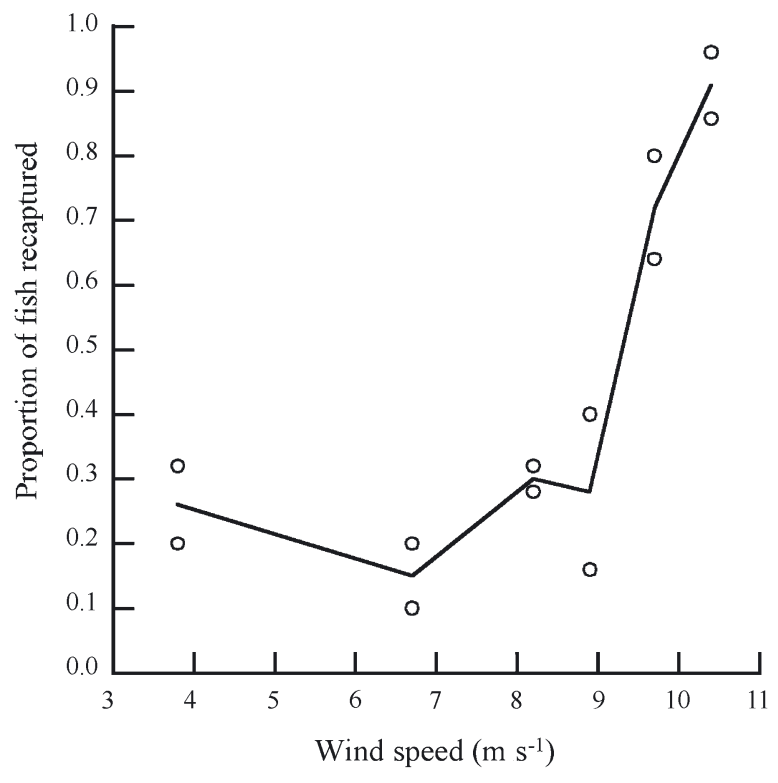

Fig. 4. Sillaginodes punctata. Effects of onshore wind speeds on proportion of larvae recaptured along Side B of cage structures. Lowess smoother fitted to regression model. Each data point represents the proportion of post-larvae recaptured out of total 25 originally placed in cage structures

(Table 3). In particular, the seaward side of cages (Side B), where a significantly higher proportion of recaptures was found, had similar length distributions across all wind conditions (Fig. 6). Standard lengths did, however, vary significantly amongst wind conditions during the experiment (Table 3, Fig. 6). The standard lengths of larvae were significantly smaller when the wind was along- rather than onshore (Tukey's test, $\mathrm{p}=0.007$ ) or offshore (Tukey's test, $\mathrm{p}=$ 0.017). No significant interaction between wind condition and cage side was found.

Current measurements with and without the cage mesh on 14 November 2001 showed a reversal in current direction over the sampling period associated with a change of tidal direction, and variation in current speed with higher speeds in the middle of the period (Table 4). There was no strong effect of the cage mesh

Table 3. Sillaginodes punctata. Results of 2-factor analysis of variance of wind direction (onshore, offshore and alongshore) and side for standard length (SL). Bold values indicate significance at $\mathrm{p}<0.05$

\begin{tabular}{|lrccc|}
\hline Source & df & MS & $F$ & $p$ \\
\hline Wind & 2 & 5.480 & 5.824 & $\mathbf{0 . 0 0 4}$ \\
Side & 3 & 0.633 & 0.673 & 0.571 \\
Wind $\times$ Side & 6 & 0.768 & 0.816 & 0.560 \\
Residual & 85 & 0.941 & & \\
& & & & \\
\hline
\end{tabular}

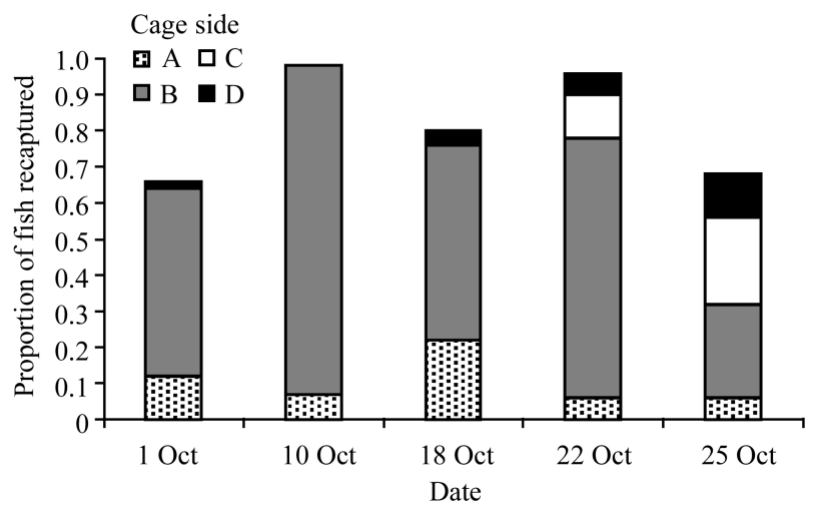

Fig. 5. Sillaginodes punctata. Individual sampling days when proportion of recaptured post-larvae was $>60 \%$ inside cage structures. Total of 50 post-larvae were placed in cage structures on each day

on current speed and direction over the period of the trial (Table 4). Frequency spectra of the velocity measurements taken on 22 August 2000 with the ADV showed that the peak in energy at the dominant wave frequency of approximately $0.4 \mathrm{~Hz}$ was very similar with or without the cage mesh (Fig. 7). There was no evidence of a change in high-frequency turbulence in the presence of cage mesh (Fig. 7).

\section{DISCUSSION}

This study suggests that Sillaginodes punctata postlarvae are transported offshore out of seagrass beds during wave disturbance associated with onshore winds. During onshore winds, recapture rates of postlarvae were high, and larger numbers of fish were collected on the seaward side of cages. A similar pattern, although not significant, occurred during alongshore wind conditions, a condition that also causes wave disturbance through refraction onto the coast. Furthermore, recapture rates along the seaward side of cages were positively related to onshore wind strength. During calm weather conditions associated with offshore winds, recapture rates were lower, and numbers of recaptured fish showed no difference amongst cage sides. The net movement of fish offshore during rough weather conditions is consistent with previous studies conducted at this site, when fewer post-larval S. punctata were collected in the seagrass during high wave/ onshore wind conditions (Jenkins et al. 1997, Moran et al. 2003). From these results we suggest that episodic disturbance events operating over relatively short temporal scales, for example high-wave conditions generated by onshore winds, have the potential to reentrain post-larvae into the plankton, thereby facilitating secondary dispersal. 


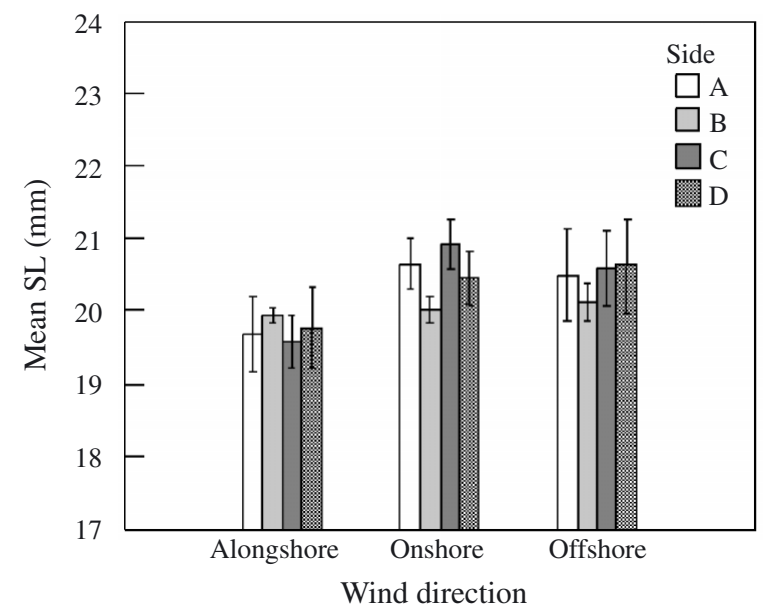

Fig. 6. Sillaginodes punctata. Standard length (SL) of postlarvae recaptured along cage sides (A-D) during wind conditions. Means $( \pm 1 \mathrm{SE})$ are shown

The vertical position of post-larvae in the water column, particularly in reference to their proximity to the tops of seagrass fronds, has important implications for their susceptibility to being re-suspended and dispersed offshore. Active depth selection has been shown to occur in larvae of coral reef fishes in offshore waters and inshore reefs (Leis et al. 1996, Leis 1999). Research on Sillaginodes punctata has shown that post-larvae are generally positioned in the lower to middle layer of the water column, directly above the seagrass canopy (Connolly 1994a, S. M. Moran pers. obs.). In this study, a small number $(\mathrm{n}=10)$ of in situ observations confirmed that post-larvae occupy the lower to middle layer of the water column, approximately $30 \mathrm{~cm}$ above the seagrass canopy. These observations were made during relatively calm weather conditions when visibility was sufficient to follow postlarvae within the seagrass beds. In a closely related study focusing on small-scale hydrodynamics among seagrass beds at Grassy Point, K. P. Black et al. (unpubl. data) found that, during onshore winds, the bulk of the mid-water column was moving in an off-

Table 4. Current speed and direction measured with and without cage mesh

\begin{tabular}{|c|c|c|c|c|}
\hline \multirow[t]{2}{*}{ Trial } & \multirow{2}{*}{$\begin{array}{c}\text { Time } \\
(\mathrm{h})\end{array}$} & \multicolumn{2}{|c|}{ Speed $\left(\mathrm{cm} \mathrm{s}^{-1}\right)$} & \multirow{2}{*}{$\begin{array}{l}\text { Avg. direction } \\
\left({ }^{\circ}\right)\end{array}$} \\
\hline & & Avg. & $\mathrm{SD}$ & \\
\hline Net on & $12: 40-12: 50$ & 2.7 & 2.32 & 13 \\
\hline Net off & 12:55-13:05 & 3.5 & 1.97 & 324 \\
\hline Net on & $13: 13-13: 23$ & 9.8 & 2.97 & 351 \\
\hline Net off & 13:26-13:36 & 9.1 & 2.51 & 315 \\
\hline Net on & $13: 39-13: 49$ & 9.9 & 2.80 & 260 \\
\hline Net off & 13:52-14:02 & 5.0 & 1.28 & 184 \\
\hline
\end{tabular}

shore direction. Post-larval S. punctata are relatively weak swimmers in the horizontal plane, with swimming speeds in the order of $6 \mathrm{~cm} \mathrm{~s}^{-1}$ (Jenkins \& Welsford 2002). Because mean current velocities, and especially orbital velocities, generally exceeded this level in onshore conditions (K. P. Black et al. unpubl. data), passive transport of $S$. punctata during onshore winds seems likely.

One factor that can influence the swimming abilities of fish larvae is their size (Wardle 1997). For fish larvae, general theory suggests a positive relationship between swimming speed and size (Stobutzki \& Bellwood 1994, Bellwood \& Fisher 2001). This relationship can ultimately influence whether larvae maintain their position in or around a particular settlement habitat, or be subjected to further dispersal in response to physi-

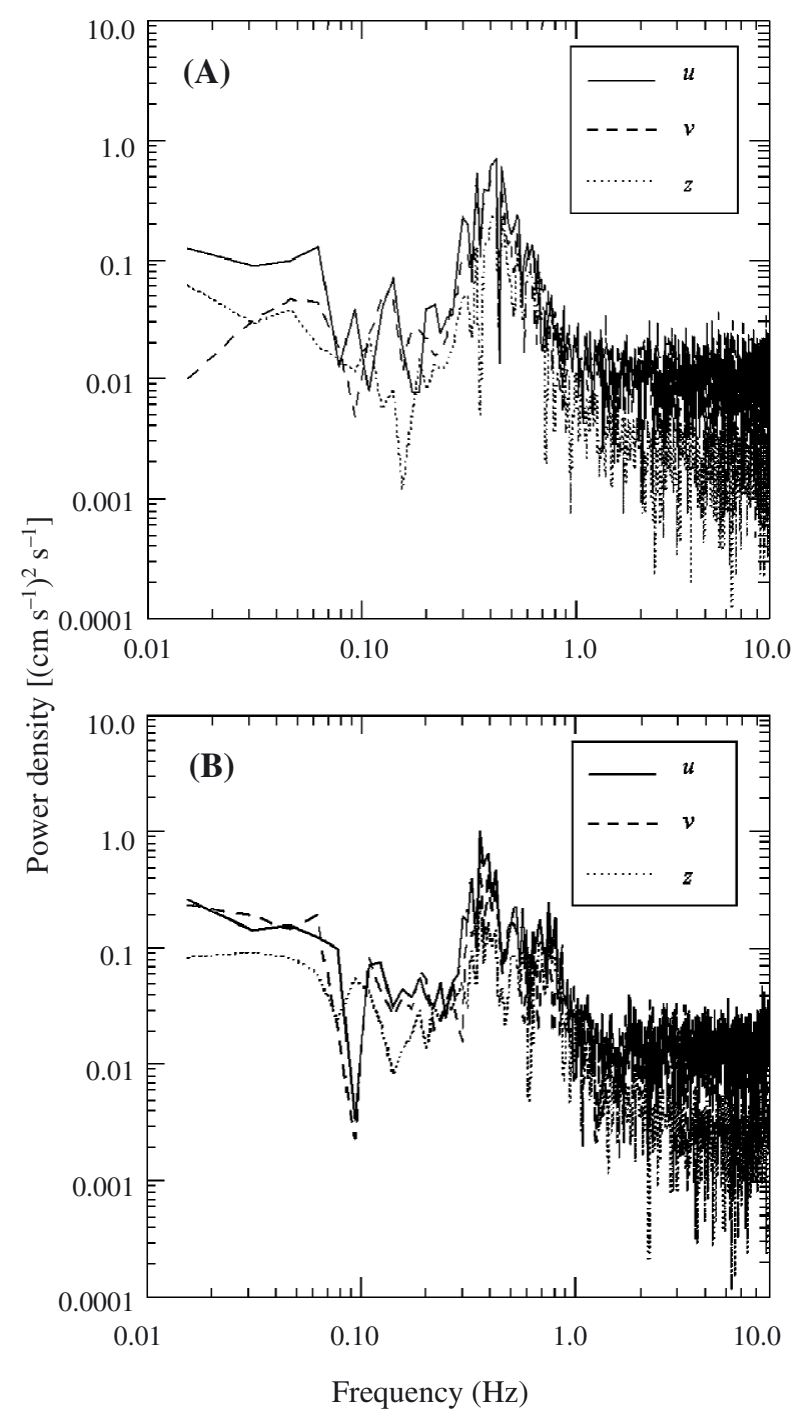

Fig. 7. Current speed spectra above seagrass canopy. Continuous line, $u$ direction; dashed line, $v$ direction; dotted line, $z$ direction. (A) Cage net mesh present, (B) cage mesh absent 
cal disturbance. Size is important in determining secondary planktonic dispersal for the blue crab Callinectus sapidus (Blackmon \& Eggleston 2001), where larger instars are more likely to undergo secondary planktonic dispersal. In our study we found no significant difference in size amongst the cage sides that would suggest a differential effect of size on secondary dispersal. However, the relatively narrow size-range of post-larvae used in the experiment makes interpretation of the results difficult.

The patterns of dispersal shown by Sillaginodes punctata in our caging experiment, suggesting offshore movements, contradict the 'settle and stay' hypothesis proposed by Bell \& Westoby (1986). The first part of this hypothesis predicts that fish larvae should settle indiscriminately in seagrass patches, regardless of patch structure. Previous studies on $S$. punctata were in agreement with this, with settlement of larvae in seagrass beds being largely unrelated to seagrass structure (Jenkins et al. 1998). However, through recent high-frequency sampling in seagrass beds (Hamer \& Jenkins 1996, Jenkins et al. 1997) the remaining prediction of the 'settle and stay' hypothesis has come into question. These studies have shown that once $S$. punctata arrive in seagrass patches they do not necessarily stay in that patch for long. However, it was not possible to distinguish between dispersal through resuspension or mortality. Moran et al. (2003) have recently suggested that secondary dispersal is a possible mechanism accounting for the significant reduction of post-larvae collected in seagrass beds during increased physical disturbance, although mortality through physical injury caused by wave action was also discussed. However, the present study has shown that mortality driven by physical injury cannot account for variability in post-larval abundance during physical disturbance associated with rough weather. In this study we found that a high proportion of post-larvae added to experimental cages during rough weather were later recaptured. Furthermore, regardless of calm or rough weather conditions, all post-larvae that were recaptured in cages were still alive. Therefore, these results suggest that mortality in rough weather may not significantly influence this species over the timescales studied.

Experimental cages have been widely used in fish predation studies (Doherty \& Sale 1985, Hindell et al. 2000a), and as a consequence much information is available on possible confounding by cage artifacts (e.g. Virnstein 1978, Connell 1997). For example, baffling effects by the materials used to construct cage structures may alter flow patterns, thus artificially confounding experimental results. However, our studies found that flow direction and velocity, wave energy and high-frequency turbulence above the seagrass were not greatly affected by the presence of cage mesh. Therefore, the results found in this study are a reliable indication of what is actually occurring in the seagrass beds and not simply an artifact of cage structures.

To summarise, the distribution of the post-larvae inside the cages suggests that Sillaginodes punctata move in an offshore (seaward) direction during disturbance from high waves generated by onshore winds. The rate of offshore movement increased with increasing wind speed but was not related to post-larval size. Our results suggest that physical disturbance, at the seagrass bed scale, has the potential to alter recruitment patterns of $S$. punctata by facilitating secondary dispersal. The observation that secondary dispersal occurs in settlement-stage $S$. punctata, and potentially redistributes fish amongst seagrass beds, demonstrates that settlement is a dynamic, protracted event, rather than the discrete event often documented in other systems.

Acknowledgements. We wish to thank D. Hatton for assistance with field sampling and oceanographic instrumentation. Thanks to L. Morris and 4 anonymous reviewers for reading and improving earlier versions of this manuscript. The Australian Research Council provided funding for this project.

\section{LITERATURE CITED}

Bell JD, Pollard DA (1989) Ecology of fish assemblages and fisheries associated with seagrasses. In: Larkum AWD, McComb AJ, Shepherd SA (eds) Biology of seagrasses: a treatise on the biology of seagrasses with special reference to the Australian region. Elsevier, Amsterdam, p 565-609

Bell JD, Westoby M (1986) Variation in seagrass height and density over a wide spatial scale: effects on common fish and decapods. J Exp Mar Biol Ecol 104:275-295

Bellwood D, Fisher R (2001) Relative swimming speeds in reef fish larvae. Mar Ecol Prog Ser 211:299-303

Black K, Hatton D, Rosenberg M (1993) Locally and externally-driven dynamics of a large semi-enclosed bay in southern Australia. J Coast Res 9:509-538

Blackmon DC, Eggleston DB (2001) Factors influencing planktonic, post-settlement dispersal of early juvenile blue crabs (Callinectes sapidus Rathbun). J Exp Mar Biol Ecol 257:183-203

Booth DJ, Hixon MA (1999) Food ration and condition affect early survival of the coral reef damselfish, Stegastes partitus. Oecologia 121:364-368

Bruce BD (1995) Larval development of King George whiting, Sillaginodes punctata, school whiting, Sillago bassensis, and yellow fin whiting, Sillago schomburgkii (Percoidei: Sillaginidae), from South Australian waters. Fish Bull US 93:27-43

Butman CA (1987) Larval settlement of soft-sediment invertebrates: the spatial scales of pattern explained by active habitat selection and the emerging role of hydrodynamical processes. Oceanogr Mar Biol Annu Rev 25: 113-165 
Caley MJ, Carr MH, Hixon MA, Hughes TP, Jones GP, Menge BA (1996) Recruitment and the local dynamics of open marine populations. Annu Rev Ecol Syst 27: $477-500$

Commito JA, Thrush SF, Pridmore RD, Hewitt JE, Cummings VJ (1995) Dispersal dynamics in a wind-driven benthic system. Limnol Oceanogr 40:1513-1518

Connell SD (1997) Exclusion of predatory fish on a coral reef: the anticipation, pre-emption and evaluation of some caging artifacts. J Exp Mar Biol Ecol 213:181-198

Connell SD, Jones GP (1991) The influence of habitat complexity on postrecruitment processes in a temperate reef fish population. J Exp Mar Biol Ecol 151:271-294

Connolly RM (1994a) The role of seagrass as preferred habitat for juvenile Sillaginodes punctata (Cuv. \& Val.) (Sillaginidae, Pisces): habitat selection or feeding? J Exp Mar Biol Ecol 180:39-47

Connolly RM (1994b) Removal of seagrass canopy: effects on small fish and their prey. J Exp Mar Biol Ecol 184: 99-110

Doherty P, Fowler T (1994) An empirical test of recruitment limitation in a coral reef fish. Science 263:935-939

Doherty PJ, Sale PF (1985) Predation on juvenile coral reef fishes: an exclusion experiment. Coral Reefs 4:225-234

Doherty PJ, Williams DM (1988) The replenishment of coral reef fish populations. Oceanogr Mar Biol Annu Rev 26: 487-551

Edgar GJ, Robertson AI (1992) The influence of seagrass structure on the distribution and abundance of mobile epifauna: pattern and process in a Western Australian Amphibolis bed. J Exp Mar Biol Ecol 160:13-31

Etherington LL, Eggleston DB (2000) Large-scale blue crab recruitment: linking postlarval transport, post-settlement planktonic dispersal, and multiple nursery habitats. Mar Ecol Prog Ser 204:179-198

Hamer PA, Jenkins GP (1996) Larval supply and short-term recruitment of a temperate demersal fish, the King George whiting, Sillaginodes punctata Cuvier and Valenciennes, to an embayment in south-eastern Australia. J Exp Mar Biol Ecol 208:197-214

Heck KL, Orth RJ (1980) Seagrass habitats: the roles of habitat complexity, competition and predation in structuring associated fish and motile macroinvertebrate assemblages. In: Kennedy VS (ed) Estuarine perspectives. Academic Press, New York, p 449-464

Hindell JS, Jenkins GP, Keough MJ (2000a) Evaluating the impact of predation by fish on the assemblage structure of fishes associated with seagrass (Heterozostera tasmanica) (Martens ex Ascherson) den Hartog, and unvegetated sand habitats. J Exp Mar Biol Ecol 255:153-174

Hindell JS, Jenkins GP, Keough MJ (2000b) Variability in abundances of fishes associated with seagrass habitats in relation to diets of predatory fishes. Mar Biol 136:725-737

Hixon MA (1998) Population dynamics of coral-reef fishes: controversial concepts and hypotheses. Aust J Ecol 23: 192-201

Jenkins GP (1986) Composition, seasonality and distribution of ichthyoplankton in Port Phillip Bay, Victoria. J Exp Mar Biol Ecol 37:507-520

Jenkins GP, Hamer PA (2001) Spatial variation in the use of seagrass and unvegetated habitats by post-settlement King George whiting (Percoidei: Sillaginidae) in relation to meiofaunal distribution and macrophyte structure. Mar Ecol Prog Ser 224:219-229

Jenkins GP, May HMA (1994) Variation in settlement and larval duration of King George Whiting, Sillaginodes punctata (Sillaginidae), in Swan Bay, Victoria, Australia.
Bull Mar Sci 54:281-296

Jenkins GP, Welsford DC (2002) The swimming abilities of recently settled post-larvae of a temperate demersal fish, the King George whiting, Sillaginodes punctata. J Fish Biol 60:1043-1050

Jenkins GP, Wheatley MJ (1998) The influence of habitat structure on nearshore fish assemblages in a southern Australian embayment: comparison of shallow seagrass, reef algal, and unvegetated habitats, with emphasis on their importance to recruitment. J Exp Mar Biol Ecol 221: $147-172$

Jenkins GP, Watson GF, Hammond LS, Black KP, Wheatley MJ, Shaw C (1996a) Importance of shallow water, reefalgal habitats as nursery areas for commercial fish from southeastern Australia. Marine and Freshwater Resources Institute, Fisheries Research and Development Corporation 92/44, Queenscliff

Jenkins GP, Wheatley MJ, Poore AGB (1996b) Spatial variation in recruitment, growth and feeding of post-settlement King George whiting, Sillaginodes punctata, associated with seagrass beds of Port Phillip Bay, Australia. Can J Fish Aquat Sci 53:350-359

Jenkins GP, Black KP, Wheatley MJ, Hatton DN (1997) Temporal and spatial variability in recruitment of a temperate, seagrass-associated fish is largely determined by physical processes in the pre- and post-settlement phases. Mar Ecol Prog Ser 148:23-35

Jenkins GP, Keough MJ, Hamer PA (1998) The contribution of habitat structure and larval supply to broad-scale recruitment variability in a temperate zone, seagrass-associated fish. J Exp Mar Biol Ecol 226:259-278

Jenkins GP, Black KP, Keough MJ (1999) The role of passive transport and the influence of vertical migration on the pre-settlement distribution of a temperate, demersal fish: model predictions compared with field sampling. Mar Ecol Prog Ser 184:259-271

Keough MJ (1984) Dynamics of the epifauna of the bivalve Pinna bicolor: interactions among recruitment, predation and competition. Ecology 65:677-688

Keough MJ, Downes BJ (1982) Recruitment of marine invertebrates: the role of active larval choices and early mortality. Oecologia 54:348-352

Leis JM (1991) Vertical distribution of fish larvae in the Great Barrier Reef Lagoon, Australia. Mar Biol 109: $157-166$

Leis JM, Sweatman HPA, Reader SE (1996) What the pelagic stages of coral reef fishes are doing out in blue water: daytime field observations of larval behavioural capabilities. Mar Freshw Res 47:401-411

Levin PS, Hay ME (1996) Responses of temperate reef fishes to alterations in algal structure and species composition. Mar Ecol Prog Ser 134:37-47

Levin PS, Petrik R, Malone J (1997) Interactive effects of habitat selection, food supply and predation on recruitment of an estuarine fish. Oecologia 112:55-63

Martel A, Chia FS (1991) Drifting and dispersal of small bivalves and gastropods with direct development. J Exp Mar Biol Ecol 150:131-147

Moran SM, Jenkins GP, Keough MJ, Hindell JS (2003) The role of physical disturbance in structuring fish assemblages in seagrass beds in Port Phillip Bay, Australia. Mar Ecol Prog Ser 251:127-139

Olivier F, Vallet C, Dauvin JC, Retiere C (1996) Drifting in post-larvae and juveniles in an Abra alba (Wood) community of the eastern part of the Bay of Seine (English Channel). J Exp Mar Biol Ecol 199:89-109

Orth RJ (1992) A perspective on plant-animal interactions in 
seagrasses: physical and biological determinants influencing plant and animal abundance. In: John DM, Hawkins SJ, Price JH (eds) Plant-animal interactions in the marine benthos. Clarendon Press, Oxford, p 147-164

Orth RJ, Heck KL, Van Montfrans J (1984) Faunal communities in seagrass beds: a review of the influence of plant structure and prey characteristics on predator-prey relationships. Estuaries 7:339-350

Palmer MA, Allan JD, Butman CA (1996) Dispersal as a regional process affecting the local dynamics of marine and stream benthic invertebrates. TREE 11:322-326

Rijnsdorp AD, van Stralen M, van der Veer HW (1985) Selective tidal transport of North Sea plaice larvae Pleuronectes platessa in coastal nursery areas. Trans Am Fish Soc 114: 461-470

Roughgarden J, Gaines S, Possingham H (1988) Recruitment dynamics in complex life cycles. Science 241: 1460-1466

Sogard SM, Powell GVN, Holmquist JG (1989) Spatial distribution and trends in abundance of fishes residing in seagrass meadows on Florida Bay mudbanks. Bull Mar Sci 44: 179-199

Editorial responsibility: Otto Kinne (Editor), Oldendorf/Luhe, Germany
Stobutzki IC, Bellwood DR (1994) An analysis of the sustained swimming abilities of pre- and post-settlement coral reef fishes. J Exp Mar Biol Ecol 175:275-286

Thiebaut E, Dauvin JC, Wang Z (1996) Tidal transport of Pectinaria koreni postlarvae (Annelida: Polychaeta) in the Bay of Seine (eastern English Channel). Mar Ecol Prog Ser 138:63-70

Turner SJ, Grant J, Pridmore RD, Hewitt JE, Wilkinson MR, Hume TM, Morrisey DJ (1997) Bedload and water-column transport and colonization processes by post-settlement benthic macrofauna - does infaunal density matter. J Exp Mar Biol Ecol 216:51-75

Underwood AJ, Keough MJ (2001) Supply-side ecology: the nature and consequences of variations in recruitment of intertidal organisms. In: Bertness MD, Gaines SD, Hay ME (eds) Marine community ecology. Sinauer, Sunderland, MA, p 183-200

Virnstein RW (1978) Predator caging experiments in soft sediments: caution advised. In: Wiley ML (ed) Estuarine interactions. Academic Press, New York, p 261-273

Wardle C (1997) Effects of size on the swimming speeds of fish. In: Pedley TJ (ed) Scale effects in animal locomotion.

Submitted: July 7, 2002; Accepted: January 8, 2004 Proofs received from author(s): May 17, 2004 